\title{
Early Glycemic Response Predicts Achievement of Subsequent Treatment Targets in the Treatment of Type 2 Diabetes: A Post hoc Analysis
}

\author{
Haoda $\mathrm{Fu} \cdot$ Dachuang Cao $\cdot$ Kristina S. Boye · Bradley Curtis • \\ Dara L. Schuster · David M. Kendall · Haya Ascher-Svanum
}

To view enhanced content go to www.diabetestherapy-open.com Received: March 27, 2015 / Published online: July 5, 2015

(C) The Author(s) 2015. This article is published with open access at Springerlink.com

\section{ABSTRACT}

Introduction: American Diabetes Association consensus guidelines emphasize individualized treatment in the management of type 2 diabetes mellitus (T2DM). Early glycemic response is a clinical marker that may predict longer term efficacy for individual patients and provide a clinical tool to enhance personalized treatment. This analysis evaluated whether glycemic response measured at week 12 ("early") could serve as a reliable predictor of glycemic control at weeks 24 and 52 of therapy in patients with T2DM.

Methods: We used data from 3 randomized, controlled clinical trials that evaluated patients with T2DM treated with 3 commonly prescribed glucose-lowering medications: metformin $(n=597)$, sulfonylurea $(n=626)$, and insulin glargine $(n=1046)$. The gradient boosting

Electronic supplementary material The online version of this article (doi:10.1007/s13300-015-0119-x) contains supplementary material, which is available to authorized users.

H. Fu $(\bowtie) \cdot$ D. Cao · K. S. Boye · B. Curtis .

D. L. Schuster - D. M. Kendall · H. Ascher-Svanum

Eli Lilly and Company, Lilly Corporate Center,

Indianapolis, IN 46285, USA

e-mail: fu_haoda@lilly.com method was used to identify predictors of subsequent response; predictive accuracy was represented by sensitivity, specificity, positive predictive value (PPV), and negative predictive value (NPV). Treatment success at weeks 24 and 52 was assessed for each patient and defined as achieving a glycated hemoglobin $\left(\mathrm{HbA}_{1 \mathrm{c}}\right)$ level of $<7.0 \%$ or a reduction from baseline of $\geq 1.0 \%$. Results: The predictive parameters (sensitivity, specificity, PPV, and NPV) for improvements in $\mathrm{HbA}_{1 \mathrm{c}}$ at week 24 for metformin were $0.83,0.81$, 0.44 , and 0.96; for sulfonylurea, 0.79, 0.94, 0.71 , and 0.96; and for insulin glargine, 0.67, $0.89,0.65$, and 0.90 . The predictive parameters for improvements in $\mathrm{HbA}_{1 \mathrm{c}}$ at week 52 for metformin were $0.73,0.84,0.56$, and 0.92 and for sulfonylurea, $0.45,0.94,0.74$, and 0.82 .

Conclusion: High predictive values identified in this analysis support "early" response as an appropriate tool for predicting treatment success at weeks 24 and 52. The high NPV (lack of early glycemic response) appears to be an effective indicator of the likely need for change in (or intensification of) therapy. These data support the current guideline recommendations that clinicians evaluate therapeutic responses to pharmacologic 
interventions with metformin, sulfonylureas, or insulin glargine as early as week 12 .

Keywords: Early response; Glycemic control; Gradient boosting; Insulin glargine; Metformin; Predictive values; Sulfonylurea; Type 2 diabetes

\section{INTRODUCTION}

Type 2 diabetes mellitus (T2DM) has become a global epidemic. The prevalence of diabetes in 2013 was 382 million people and is expected to increase to 592 million people by the year 2035 [1]. While a myriad of glucose-lowering therapies are available, many patients with T2DM still do not reach treatment goals [2-4], exposing them to the risk of debilitating and costly complications. Joint guidelines from the American Diabetes Association (ADA) and the European Association for the Study of Diabetes (EASD) recommend a patient-centered, personalized approach for the treatment of diabetes, tailored to patients' individual needs and preferences along with considerations that include age, weight, comorbidities and complications, patient attitude, risk of hypoglycemia, disease duration, life expectancy, and available resources [5]. Reliable, affordable, and convenient early markers used commonly in clinical practice and demonstrated to be predictive of longterm results may facilitate a personalized approach to therapy.

Early response to medication has been demonstrated to be a robust predictor of subsequent response to the medication across multiple therapeutic areas; in particular, lack of early response predicts lack of subsequent response. This early-response phenomenon has been observed in the treatment of schizophrenia with antipsychotics [6-10], bipolar disorder with antidepressants [11], major depressive disorder with antidepressants [12], attention-deficit/hyperactivity disorder with a selective norepinephrine reuptake inhibitor [13, 14], plaque psoriasis with monoclonal antibody therapy [15], rheumatoid arthritis with monoclonal antibody therapy [16], and breast cancer with neoadjuvant chemotherapy [17]. Little is known about this early-response phenomenon in the treatment of diabetes. Accurate predictions of response to medication have notable implications for clinical improvements, treatment choices or transitions, and healthcare costs by helping clinicians make early treatment decisions for patients who are unlikely to be responsive to their current therapies and minimizing the time patients spend on suboptimal treatment regimens [18-22].

In T2DM, Karl et al. [23] demonstrated that 6-month glycemic responses to insulin glargine can be predicted after 6-12 weeks of therapyspecifically, fasting plasma glucose $>180.2 \mathrm{mg} /$ $\mathrm{dL}(10 \mathrm{mmol} / \mathrm{L})$ after $6-12$ weeks of insulin glargine therapy indicated that reaching a glycated hemoglobin $\left(\mathrm{HbA}_{1 \mathrm{c}}\right)$ level target of $\leq 7.0 \%$ was unlikely-and thereby provided a means for predicting response to therapy early in the treatment approach; however, the predictive accuracy of this method was unclear. Given the limited understanding of early glycemic response to glucose-lowering medication, it is currently unclear whether early response to glucose-lowering medication is a robust predictor of subsequent response.

To help address this important information gap, this analysis assessed the predictive power of early response for subsequent response across 3 commonly prescribed glucose-lowering medications: metformin, sulfonylurea, and insulin glargine. We hypothesized that glycemic response at week 12 (early response) 
predicts subsequent glycemic responses at week 24 (the primary outcome) and week 52 (the secondary outcome) in the treatment of patients with T2DM.

\section{METHODS}

\section{Study design}

To evaluate the hypothesis for the 3 commonly prescribed glucose-lowering medications of metformin, sulfonylurea, and insulin glargine, 3 previously published, randomized clinical trials that included large samples with individual patient data were used for this study (Table 1).

Metformin data $(n=597)$ were obtained from a trial that compared the glycemic control of metformin and pioglitazone in 1199 randomized, glucose-lowering drug-naive patients with poorly controlled T2DM over 52 weeks [24].

Sulfonylurea data $(n=626)$ were obtained from a trial that compared the glycemic control of the sulfonylurea gliclazide and the thiazolidinedione pioglitazone in 1270 randomized, drug-naive patients with poorly controlled T2DM over 52 weeks [25].

Insulin glargine data $(n=1046)$ were obtained from a trial that compared the durability of glycemic control of once-daily insulin glargine and twice-daily insulin lispro during a 6-month initiation phase in 2091 randomized patients with T2DM on oral glucose-lowering medications [26]. Patients with $\mathrm{HbA}_{1 \mathrm{c}}$ levels of $\leq 7.0 \%$ at the end of the initiation phase continued in a maintenance phase for up to 24 months. Because only selected patients were monitored during the 24-month maintenance phase, the trial design did not permit 52-week follow-up for insulin glargine data in the current analysis.

Glycemic control for each of the 3 trials is shown in Table 2. Data from patients with nonmissing $\mathrm{HbA}_{1 \mathrm{c}}$ level values at baseline and weeks 12, 24, and 52 from the aforementioned clinical trials were analyzed. Treatment success at week 24 (the primary outcome) and week 52 (the secondary outcome) was assessed for each patient and defined as an $\mathrm{HbA}_{1 \mathrm{c}}$ level reduction

Table 1 Randomized clinical trials from which data were pooled for this analysis

\begin{tabular}{|c|c|c|c|c|}
\hline Study & Treatment & $\begin{array}{l}\text { Trial sample } \\
\text { size }\end{array}$ & $\begin{array}{l}\text { Sample size used } \\
\text { in this analysis }\end{array}$ & Design \\
\hline $\begin{array}{l}\text { Schernthaner } \\
\text { et al. }[24]\end{array}$ & Met $^{\mathrm{a}}$ vs. pio & 1199 & 597 & $\begin{array}{l}\text { 12-week titration } \\
\text { 40-week maintenance }\end{array}$ \\
\hline $\begin{array}{l}\text { Charbonnel } \\
\text { et al. }[25]\end{array}$ & $S U^{\mathrm{a}}$ vs. pio & 1270 & 626 & $\begin{array}{l}\text { 16-week titration } \\
\text { 36-week maintenance }\end{array}$ \\
\hline Buse et al. [26] & $\begin{array}{l}\text { Glargine }^{\mathrm{a}} \text { vs. } \\
\text { lispro }\end{array}$ & 2091 & 1046 & $\begin{array}{l}\text { OADs } \\
\text { 6-month initiation phase } \\
\text { If } \mathrm{HbA}_{1 \mathrm{c}} \leq 7.0 \% \text {, then 24-month } \\
\text { maintenance }\end{array}$ \\
\hline
\end{tabular}

Glargine insulin glargine, Lispro insulin lispro, Met metformin, $O A D$ oral anti-hyperglycemic medication, Pio pioglitazone, $S U$ sulfonylurea, $H b A_{1 c}$ glycated hemoglobin

a Treatment arm included in present analysis 
Table 2 Glycemic control

\begin{tabular}{|c|c|c|c|c|}
\hline Measure & Time point & Met $(N=597)$ & SU $(N=626)$ & Glargine $(N=1046)$ \\
\hline \multirow[t]{4}{*}{$\mathrm{HbA}_{1 \mathrm{c}}(\%)$} & Baseline & $8.7(1.0)$ & $8.7(1.1)$ & $8.9(1.3)$ \\
\hline & Week 12 & $7.5(1.1)$ & $7.2(1.1)$ & $7.6(1.1)$ \\
\hline & Week 24 & $7.1(1.0)$ & $7.0(1.1)$ & $7.4(1.2)$ \\
\hline & Week 52 & $7.2(1.1)$ & $7.3(1.2)$ & NA \\
\hline \multirow[t]{3}{*}{$\mathrm{HbA}_{\mathrm{lc}}$ change $^{\mathrm{a}}(\%)$} & Week 12 & $-1.1(1.0)$ & $-1.5(1.0)$ & $-1.4(1.2)$ \\
\hline & Week 24 & $-1.6(1.2)$ & $-1.7(1.1)$ & $-1.5(1.3)$ \\
\hline & Week 52 & $-1.5(1.2)$ & $-1.3(1.1)$ & NA \\
\hline \multirow[t]{4}{*}{ FBG $(\mathrm{mmol} / \mathrm{L})$} & Baseline & $11.3(2.8)$ & $11.2(2.9)$ & $10.1(4.0)$ \\
\hline & Week 12 & $9.0(2.4)$ & $8.5(2.4)$ & $7.2(3.0)$ \\
\hline & Week 24 & $8.7(2.3)$ & $8.4(2.4)$ & $7.0(2.7)$ \\
\hline & Week 52 & $9.1(2.5)$ & $9.3(3.0)$ & NA \\
\hline \multirow[t]{3}{*}{ FBG change $^{\mathrm{a}}(\mathrm{mmol} / \mathrm{L})$} & Week 12 & $-2.2(2.5)$ & $-2.7(2.7)$ & $-2.9(3.5)$ \\
\hline & Week 24 & $-2.5(2.7)$ & $-2.8(2.8)$ & $-3.2(3.7)$ \\
\hline & Week 52 & $-2.1(2.9)$ & $-2.0(2.9)$ & NA \\
\hline
\end{tabular}

Mean (standard deviation) shown

$F B G$ fasting blood glucose measure, Glargine insulin glargine, Met metformin, $N A$ not applicable, $S U$ sulfonylurea, $H b A_{1 c}$ glycated hemoglobin

${ }^{a}$ Change from baseline

of $\geq 1.0 \%$ or an $\mathrm{HbA}_{1 \mathrm{c}}$ level of $<7.0 \%$. Thus, a patient needed to meet 1 of the 2 success criteria by reaching either an $\mathrm{HbA}_{1 \mathrm{c}}$ reduction of $\geq 1.0 \%$ or an $\mathrm{HbA}_{1 \mathrm{c}}$ level of $<7.0 \%$ to be considered having achieved treatment success.

The use of an $\mathrm{HbA}_{1 \mathrm{c}}$ level reduction of $\geq 1.0 \%$ as the threshold value in this analysis was selected because of its clinical relevance in diabetes management. The UK Prospective Diabetes Study showed that every $1.0 \%$ reduction in mean $\mathrm{HbA}_{1 \mathrm{c}}$ level was associated with reductions of $21 \%$ for any diabetes-related endpoint, $21 \%$ for diabetes-related deaths, $14 \%$ for myocardial infarctions, and $37 \%$ for microvascular complications [27]. Further, the National Institute for Health and Care Excellence guideline selected an $\mathrm{HbA}_{1 \mathrm{c}}$ level reduction of $\geq 1.0 \%$ with the use of glucagonlike peptide- 1 receptor agonists as a threshold criterion for continuing therapy $[28,29]$. The use of an $\mathrm{HbA}_{1 \mathrm{c}}$ level of $<7.0 \%$ was selected because it is consistent with the ADA recommended $\mathrm{HbA}_{1 \mathrm{c}}$ target value [30].

\section{Gradient Boosting Method}

The gradient boosting method was applied to the dataset from each trial to identify the optimal early-response variable, defined as the variable with the largest relative inference among the candidate variables for subsequent response prediction [31]. Candidate earlyresponse variables were based on $\mathrm{HbA}_{1 \mathrm{c}}$ levels at week 12 of $<7.4 \%,<7.3 \%,<7.2 \%, \ldots,<6.6 \%$; 
Table 3 Sensitivity and specificity

\begin{tabular}{lll}
\hline $\begin{array}{l}\text { Early-response } \\
\text { treatment } \\
\text { success }\end{array}$ & $\begin{array}{l}\text { Subsequent response } \\
\text { treatment success }\end{array}$ \\
\cline { 2 - 3 } & Yes & No \\
\hline Yes & $\mathrm{A}$ & $\mathrm{B}$ \\
& True positive & False positive \\
No & $\mathrm{C}$ & $\mathrm{D}$ \\
& False negative $^{\mathrm{b}}$ & True negative \\
\hline
\end{tabular}

Positive predictive value $(\mathrm{PPV})=\mathrm{A} /(\mathrm{A}+\mathrm{B})$

Negative predictive value $(\mathrm{NPV})=\mathrm{D} /(\mathrm{C}+\mathrm{D})$

${ }^{a}$ False positive results indicate the specificity of the analysis [38]. Few false positive results denote high specificity. Specificity $=D /(B+D)$

b False negative results indicate the sensitivity of the analysis. Few false negative results denote high sensitivity. Sensitivity $=\mathrm{A} /(\mathrm{A}+\mathrm{C})$

a reduction in $\mathrm{HbA}_{1 \mathrm{c}}$ level of $\geq 1.3 \%, \geq 1.2 \%$, $\geq 1.1 \%, \ldots, \geq 0.5 \%$; fasting blood glucose (FBG) levels at week 12 of $<12.5,<12.0,<11.5, \ldots$, $<8.5 \mathrm{mmol} / \mathrm{L}$; and a reduction in FBG level of $\geq 4.5, \geq 4.0, \geq 3.5, \ldots, \geq 0.5 \mathrm{mmol} / \mathrm{L}$.

Predictive parameters included sensitivity, which is the percentage of subsequent responders correctly identified; specificity, the percentage of subsequent non-responders correctly identified; positive predictive value (PPV), the percentage of subsequent responders among early responders; and negative predictive value (NPV), the percentage of subsequent non-responders among early nonresponders (Table 3).

\section{Correlation Coefficients}

Correlation coefficients for $\mathrm{HbA}_{1 \mathrm{c}}$ level and $\mathrm{HbA}_{1 \mathrm{c}}$ level change were assessed using the Pearson product-moment correlation method [32]. The analysis was conducted in SAS 9.0 (SAS Institute Inc., Cary, NC, USA).

\section{RESULTS}

\section{Patient Disposition and Demographics}

Data from 2269 patients were included in this analysis (Table 1). For metformin, sulfonylurea, and insulin glargine, $79 \%, 83 \%$, and $85 \%$ of patients with available $\mathrm{HbA}_{1 \mathrm{c}}$ data at baseline were assessed at week 12 and week 24 (Table 4). For metformin and sulfonylurea, $72 \%$ and $75 \%$ of patients also had $\mathrm{HbA}_{1 \mathrm{c}}$ assessed at week 52 .

Across studies, the mean age was 56 or 57 years, the mean body weight was 88 or $90 \mathrm{~kg}$, the mean body mass index was 31 or $32 \mathrm{~kg} / \mathrm{m}^{2}$, and the mean $\mathrm{HbA}_{1 \mathrm{c}}$ level was $8.7 \%$ or $9.0 \%$ (Table 4 ). The percentage of male patients ranged from $53 \%$ to $62 \%$, and the mean FBG level ranged from 10.9 to $11.3 \mathrm{mmol} /$ L. The mean duration of diabetes was 3.0 years for patients treated with metformin and sulfonylurea and 9.3 years for patients treated with insulin glargine.

\section{Predictive Parameters}

The optimal early-response variables identified by the GBM for metformin were a reduction in $\mathrm{HbA}_{1 \mathrm{c}}$ level of $\geq 0.8 \%$ at week 24 and a reduction in $\mathrm{HbA}_{1 \mathrm{c}}$ level of $\geq 0.6 \%$ at week 52 . The optimal early-response variable for sulfonylurea was a reduction in $\mathrm{HbA}_{1 \mathrm{c}}$ level of $\geq 1.0 \%$ at both week 24 and week 52 , and that for insulin glargine was a reduction in $\mathrm{HbA}_{1 \mathrm{c}}$ level of $\geq 1.0 \%$ at week 24 . Thus, for each medication, the optimal early-response variable was equal or close to a reduction in $\mathrm{HbA}_{1 \mathrm{c}}$ level of $\geq 1.0 \%$, which is considered to be clinically meaningful. Therefore, we chose a single, unified early-response measure (a reduction in $\mathrm{HbA}_{1 \mathrm{c}}$ level of $\geq 1.0 \%$ ) for all 3 medications. 
Table 4 Sample sizes for analysis populations, demographics, and patient characteristics as baseline

\begin{tabular}{|c|c|c|c|}
\hline Patient sample & $\begin{array}{l}\text { Met } \\
(N=597)\end{array}$ & $\begin{array}{l}\text { SU } \\
(N=626)\end{array}$ & $\begin{array}{l}\text { Glargine } \\
(N=1046)\end{array}$ \\
\hline $\begin{array}{l}\text { Patients with non-missing } \mathrm{HbA}_{1 \mathrm{c}} \text { at baseline, week 12, } \\
\text { and week } 24\end{array}$ & $470(79 \%)$ & $517(83 \%)$ & $886(85 \%)$ \\
\hline $\begin{array}{l}\text { Patients with non-missing } \mathrm{HbA}_{1 \mathrm{c}} \text { at baseline, week } 12 \text {, } \\
\text { week } 24 \text {, and week } 52\end{array}$ & $432(72 \%)$ & $465(74 \%)$ & NA \\
\hline \multicolumn{4}{|l|}{ Characteristic } \\
\hline Age (years) & $56 \pm 9$ & $56 \pm 10$ & $57 \pm 10$ \\
\hline Male (\%) & $345(58 \%)$ & $386(62 \%)$ & $552(53 \%)$ \\
\hline Weight (kg) & $90 \pm 17$ & $88 \pm 17$ & $88 \pm 21$ \\
\hline BMI $\left(\mathrm{kg} / \mathrm{m}^{2}\right)$ & $31 \pm 5$ & $31 \pm 5$ & $32 \pm 6$ \\
\hline Duration of diabetes (years) & $3.0 \pm 3.7$ & $3.0 \pm 3.8$ & $9.3 \pm 5.9$ \\
\hline $\mathrm{HbA}_{1 \mathrm{c}}(\%)$ & $8.7 \pm 1.0$ & $8.7 \pm 1.1$ & $9.0 \pm 1.2$ \\
\hline $\mathrm{FBG}(\mathrm{mmol} / \mathrm{L})$ & $11.3 \pm 2.8$ & $11.2 \pm 2.9$ & $10.9 \pm 3.1$ \\
\hline
\end{tabular}

Mean \pm standard deviation or $n(\%)$ are shown

$B M I$ body mass index, $F B G$ fasting blood glucose, Glargine insulin glargine, Met metformin, $S U$ sulfonylurea, $H b A_{1 c}$ glycated hemoglobin

The GBM did not select an $\mathrm{HbA}_{1 \mathrm{c}}$ level of $<7.0 \%$ as an optimal early-response variable in any case. However, since an $\mathrm{HbA}_{1 \mathrm{c}}$ level of $<7.0 \%$ is clinically meaningful, it was combined with a reduction in $\mathrm{HbA}_{1 \mathrm{c}}$ of $\geq 1.0 \%$ for a composite unified measure in assessing predictive parameters (reduction in $\mathrm{HbA}_{1 \mathrm{c}}$ level of $\geq 1.0 \%$ or $\mathrm{HbA}_{1 \mathrm{c}}$ level of $<7.0 \%$ ).

The predictive parameters for improvements in $\mathrm{HbA}_{1 \mathrm{c}}$ at week 24 and week 52, based on the composite unified early-response measure (reduction in $\mathrm{HbA}_{1 \mathrm{c}}$ level of $\geq 1.0 \%$ or $\mathrm{HbA}_{1 \mathrm{c}}$ level of $<7.0 \%$ ) for metformin were $0.83,0.81$, 0.44 , and 0.96; for sulfonylurea, 0.79, 0.94, 0.71 , and 0.96; and for insulin glargine, 0.67, $0.89,0.65$, and 0.90 . The predictive parameters for improvements in $\mathrm{HbA}_{1 \mathrm{c}}$ at week 52 for metformin were $0.73,0.84,0.56$, and 0.92 and for sulfonylurea $0.45,0.94,0.74$, and 0.82 (Table 5).
The predictive parameters assessed using the optimal early-response measure and the unified measure were consistent with those of the composite unified measure and are shown in Table 5. Across all therapies and early-response measures and at both time points, the NPV remained consistently high (range 0.82-0.98) (Table 5).

\section{Correlation Coefficients}

In the 3 studies, high correlation coefficients were observed at week 12 vs. week 24 and at week 12 vs. week 52 for $\mathrm{HbA}_{1 \mathrm{c}}$ level and change from baseline (Table 6). For $\mathrm{HbA}_{1 \mathrm{c}}$ level, the ranges for these correlation coefficients were $0.76-0.87$ at week 12 vs. week 24 and $0.72-0.73$ at week 12 vs. week 52 . For $\mathrm{HbA}_{1 \mathrm{c}}$ change, the ranges were $0.84-0.89$ at week 12 vs. week 24 and $0.76-0.80$ at week 12 vs. week 52 . 
Table 5 Predictive parameters for improvements in $\mathrm{HbA}_{1 \mathrm{c}}$ at 24 and 52 weeks based on $\mathrm{HbA}_{1 \mathrm{c}}$ levels at 12 weeks

\begin{tabular}{|c|c|c|c|c|c|c|}
\hline $\begin{array}{l}\text { Early-response } \\
\text { measure }\end{array}$ & $\begin{array}{l}\text { Subsequent } \\
\text { response }\end{array}$ & Agent & Sensitivity & Specificity & PPV & NPV \\
\hline \multirow{5}{*}{ Composite unified } & 24 weeks & Met & 0.83 & 0.81 & 0.44 & 0.96 \\
\hline & & SU & 0.79 & 0.94 & 0.71 & 0.96 \\
\hline & & Glargine & 0.67 & 0.89 & 0.65 & 0.90 \\
\hline & 52 weeks & Met & 0.73 & 0.84 & 0.56 & 0.92 \\
\hline & & SU & 0.45 & 0.94 & 0.74 & 0.82 \\
\hline \multirow[t]{5}{*}{ Unified } & 24 weeks & Met & 0.90 & 0.74 & 0.38 & 0.98 \\
\hline & & SU & 0.85 & 0.88 & 0.57 & 0.97 \\
\hline & & Glargine & 0.74 & 0.83 & 0.56 & 0.92 \\
\hline & 52 weeks & Met & 0.82 & 0.78 & 0.50 & 0.94 \\
\hline & & SU & 0.52 & 0.88 & 0.62 & 0.83 \\
\hline \multirow{5}{*}{ Optimal } & 24 weeks & Met & 0.82 & 0.81 & 0.44 & 0.96 \\
\hline & & SU & 0.85 & 0.88 & 0.57 & 0.97 \\
\hline & & Glargine & 0.74 & 0.83 & 0.56 & 0.92 \\
\hline & 52 weeks & Met & 0.56 & 0.92 & 0.67 & 0.88 \\
\hline & & SU & 0.52 & 0.88 & 0.62 & 0.83 \\
\hline
\end{tabular}

Composite unified early-response measure: $\mathrm{HbA}_{1 \mathrm{c}}$ reduction of $\geq 1.0 \%$ or $\mathrm{HbA}_{1 \mathrm{c}}$ level of $<7.0 \%$ at week 12; unified earlyresponse measure: $\mathrm{HbA}_{1 \mathrm{c}}$ reduction of $\geq 1.0 \%$; optimal early-response measure: $\mathrm{HbA}_{1 \mathrm{c}}$ reduction of $\geq 1.0 \%$ for sulfonylurea and glargine at week 24 and at week $52, \mathrm{HbA}_{1 \mathrm{c}}$ reduction of $\geq 0.8 \%$ for metformin at week 24 , and $\mathrm{HbA}_{1 \mathrm{c}}$ reduction of $\geq 0.6 \%$ for metformin at week 52

Glargine insulin glargine, Met metformin, $N P V$ negative predictive value, $P P V$ positive predictive value, $S U$ sulfonylurea, $H b A_{\text {Ic }}$ glycated hemoglobin

Table 6 Correlation coefficients

\begin{tabular}{lllll}
\hline Measure & $\begin{array}{l}\text { Time points } \\
\text { (weeks) }\end{array}$ & Met & SU & Glargine \\
\hline $\mathrm{HbA}_{1 \mathrm{c}}$ & 12 vs. 24 & 0.79 & 0.87 & 0.76 \\
& 12 vs. 52 & 0.72 & 0.73 & NA \\
$\mathrm{HbA}_{1 \mathrm{c}}$ & 12 vs. 24 & 0.85 & 0.89 & 0.84 \\
change & 12 vs. 52 & 0.80 & 0.76 & NA \\
\hline
\end{tabular}

Glargine insulin glargine, Met metformin, $N A$ not applicable, $S U$ sulfonylurea, $H b A_{1 c}$ glycated hemoglobin

\section{DISCUSSION}

In this analysis of data from 3 clinical trials including 3 different glucose-lowering therapies, we demonstrated that lack of early glycemic response at week 12 is a reliable predictor of failure to achieve glycemic treatment targets $\left(\mathrm{HbA}_{1 \mathrm{c}}<7.0 \%\right.$ or $\mathrm{HbA}_{1 \mathrm{c}}$ reduction of $\geq 1.0 \%$ ) at week 24 and week 52 . NPV is consistently high for all 3 early-response 
measures (i.e., unified composite, unified, and optimal), which indicates that the chances are $82-98 \%$ that a patient who lacks early response to a specific treatment regimen at week 12 will be unable to achieve treatment targets when continuing that regimen. The high correlation coefficients observed at week 12 vs. week 24 and week 12 vs. week 52 corroborate the effectiveness of week-12 $\mathrm{HbA}_{1 \mathrm{c}}$ level and its change from baseline as predictors for longterm response.

Predicting the lack of early glycemic response was demonstrated using a clinically meaningful unified composite measure, which included a relative $\left(\mathrm{HbA}_{1 \mathrm{c}}\right.$ reduction of $\left.\geq 1.0 \%\right)$ and an absolute $\left(\mathrm{HbA}_{1 \mathrm{c}}<7.0 \%\right)$ measure of glycemic control. The choice of a composite measure may minimize the impact of baseline $\mathrm{HbA}_{1 \mathrm{c}}$ in predicting treatment responses. For example, if a patient has a baseline $\mathrm{HbA}_{1 \mathrm{c}}$ level of $11 \%$ and a 24 -week $\mathrm{HbA}_{1 \mathrm{c}}$ level of $7.5 \%$, the patient would be considered a responder because of the clinically meaningful $\mathrm{HbA}_{1 \mathrm{c}}$ reduction of $3.5 \%$. Thus, using a composite measure of response is likely to be applicable and relevant to more patients than using either the absolute or the relative measure alone. Additional information, such as demographic variables other than $\mathrm{HbA}_{1 \mathrm{c}}$, may further improve the NPV or PPV or improve the applicability of this approach to other or more specialized patient groups.

Among the prediction parameters (sensitivity, specificity, PPV, and NPV), NPV appears to be the most relevant parameter in clinical practice because clinicians need to identify patients who do not respond optimally to current medications or patients who are unlikely to respond with continued use of the medications. Clinicians' early evaluations may help identify the potential reasons a patient failed to respond to treatment and rule out the possibility that lack of response was driven by poor patient adherence to the prescribed regimen. Thus, the availability of such early information may be used as a tool for clinicians to help identify-shortly after medication initiation-patients who require a change in the current medication regimen in the form of an increased dose, a medication switch, an augmentation with another medication, or possibly the discontinuation of the medication for a period of time to better evaluate potential underlying causes of the observed poor response to therapy. The use of early treatment information may help optimize patients' treatment outcomes by minimizing the duration of suboptimal therapy while increasing the likelihood of relevant and timely change in the medication regimen, which may also help minimize waste of resources for patients and third-party healthcare payers alike.

The increasing prevalence of T2DM increases the economic burden of diabetes care, highlighting the need for improved methods of diabetes management. Overall, poor glycemic control, along with associated comorbidities, contributes to increased resource use and costs of diabetes care [22, 33]. Most patients with T2DM do not maintain glycemic goals in routine clinical practice [24]. Many patients with T2DM may not initiate or escalate treatment approaches sufficiently early in the course of the disease to reach recommended treatment targets [19-21, 34, 35], which contributes to poor glycemic control and ultimately to increased costs. Thus, improved methods for early effective management of T2DM and associated complications are necessary, including methods for early treatment decisions.

The ADA and EASD advocate for personalized, patient-centered treatment of 
T2DM [5]. By design, recommended treatment paradigms are based on clinical trial results that involve a highly selected patient population and an artificial clinical environment [5]. However, personalized care depends on responsiveness to the needs of individual patients [36]. Predictive parameters of glycemic control, particularly NPV, may aid in personalizing patient therapy by providing a means of adapting broad, evidence-based treatment advice to individual therapeutic responses and promoting appropriate treatment regimens early in the management of diabetes.

Current findings need to be evaluated in the context of this study's limitations. We relied on data from randomized, controlled trials. Patient populations in controlled trials are highly selected; therefore, real-world results will be required to replicate the current findings, which are based on randomized clinical trials. This study defined treatment response only in terms of glycemic control, but other important treatment targets such as weight gain, hypoglycemia events, and microvascular and macrovascular complications are also critical in the management of T2DM. It would be prudent, therefore, for future research to use a composite measure that incorporates glycemic control with other treatment goals. The concept of threshold-based targets may deviate in part from the concept of individualized therapy; therefore, the definition of "responder" in this analysis may need to be further refined to include individual patient characteristics. In addition, although T2DM is a chronic illness, the current analysis focused on the first 24 and 52 weeks of therapy. Finally, this analysis focused on early response to 3 common medications in the treatment of T2DM, and additional research will be needed to assess the early-response phenomenon with various treatment regimens, especially combination therapy.

The strengths of this study include robust predictive parameters across a range of commonly prescribed glucose-lowering medications. The GBM algorithm is a highly robust statistical method without parametric model assumptions [37]. This study used relatively large sample sizes from randomized trials, which would help minimize the bias of known or unknown confounders.

\section{CONCLUSION}

The high predictive values identified in this analysis support that lack of early glycemic response is a reliable clinical marker for identifying a lack of treatment success at 24 and 52 weeks. The high NPV (lack of early glycemic response) appears to be an effective indicator of the likely need for a change in (or intensification of) therapy and could become valuable in clinical practice. Moreover, study findings support the current treatment recommendations for T2DM, which advise clinicians to evaluate therapeutic response to pharmacologic interventions with metformin, sulfonylureas, or insulin glargine as early as 12 weeks.

\section{ACKNOWLEDGMENTS}

This study and article processing charges were funded by Eli Lilly and Company (Indianapolis, IN, USA). The authors thank Joseph Giaconia (INC Research, Raleigh, NC, USA) for his medical writing assistance in the preparation of this manuscript; support for his assistance was funded by Eli Lilly and Company. All authors had full access to all of the data in this study and take complete responsibility for 
the integrity of the data and accuracy of the data analysis. All named authors meet the ICMJE criteria for authorship for this manuscript, take responsibility for the integrity of the work as a whole, and have given final approval to the version to be published.

Conflict of interest. Haoda $\mathrm{Fu}$ is an employee of and owner of stock in Eli Lilly and Company. Dachuang Cao is an employee of and owner of stock in Eli Lilly and Company. Kristina S. Boye is an employee of and owner of stock in Eli Lilly and Company. Bradley Curtis is an employee of and owner of stock in Eli Lilly and Company. Dara L. Schuster is an employee of and owner of stock in Eli Lilly and Company. David M. Kendall is an employee of and owner of stock in Eli Lilly and Company. Haya AscherSvanum is an employee of and owner of stock in Eli Lilly and Company.

Compliance with ethics guidelines. This article does not contain any new studies with human or animal subjects performed by any of the authors.

Open Access. This article is distributed under the terms of the Creative Commons Attribution Noncommercial License which permits any noncommercial use, distribution, and reproduction in any medium, provided the original author(s) and the source are credited.

\section{REFERENCES}

1. International Diabetes Foundation (2013) IDF Diabetes Atlas. 6th ed. http://www.idf.org/sites/ default/files/EN_6E_Atlas_Full_0.pdf. Accessed Mar 2015.

2. Ali MK, Bullard KM, Saaddine JB, Cowie CC, Imperatore G, Gregg EW. Achievement of goals in
US diabetes care, 1999-2010. N Engl J Med. 2013;368:1613-24.

3. Bloomgarden ZT. Achieving glycemic goals in type 2 diabetes. Diabetes Care. 2007;30:174-80.

4. Steinberg BA, Bhatt DL, Mehta S, et al. Nine-year trends in achievement of risk factor goals in the US and European outpatients with cardiovascular disease. Am Heart J. 2008;156:719-27.

5. Inzucchi SE, Bergenstal RM, Buse JB, et al. Management of hyperglycemia in type 2 diabetes: a patient-centered approach: position statement of the American Diabetes Association (ADA) and the European Association for the Study of Diabetes (EASD). Diabetes Care. 2012;35:1364-79.

6. Agid O, Kapur S, Arenovich T, Zipursky RB. Delayed-onset hypothesis of antipsychotic action: a hypothesis tested and rejected. Arch Gen Psychiatry. 2003;60:1228-35.

7. Chen L, Ascher-Svanum H, Stauffer V, Kinon BJ, Kollack-Walker S, Ruberg S. Optimal thresholds of early response to atypical antipsychotics: application of signal detection methods. Schizophr Res. 2009;113:34-40.

8. Kinon BJ, Chen L, Ascher-Svanum $\mathrm{H}$, et al. Predicting response to atypical antipsychotics based on early response in the treatment of schizophrenia. Schizophr Res. 2008;102:230-40. doi:10.1016/j.schres.2008.02.021.

9. Kishi T, Matsuda Y, Fujita K, Iwata N. Early prediction of blonanserin response in Japanese patients with schizophrenia. Neuropsychiatr Dis Treat. 2014;10:1861-6.

10. Ruberg SJ, Chen L, Stauffer V, et al. Identification of early changes in specific symptoms that predict longer-term response to atypical antipsychotics in the treatment of patients with schizophrenia. BMC Psychiatry. 2011;11:23.

11. Kemp DE, Ganocy SJ, Brecher M, et al. Clinical value of early partial symptomatic improvement in the prediction of response and remission during short-term treatment trials in 3369 subjects with bipolar I or II depression. J Affect Disord. 2011;130:171-9.

12. Vermeiden M, Kamperman AM, Vulink ME, van den Broek WW, Birkenhäger TK. Early improvement as a predictor of eventual antidepressant treatment response in severely depressed inpatients. Psychopharmacology (Berl). 2015;232(8):1347-56. doi:10.1007/s00213-0143765-1. 
13. Block SL, Williams D, Donnelly CL, Dunn DW, Saylor KE, Ruberg SJ. Post hoc analysis: early changes in ADHD-RS items predict longer term response to atomoxetine in pediatric patients. Clin Pediatr (Phila). 2010;49:768-76.

14. Newcorn JH, Sutton VK, Weiss MD, Sumner CR. Clinical responses to atomoxetine in attentiondeficit/hyperactivity disorder: the Integrated Data Exploratory Analysis (IDEA) study. J Am Acad Child Adolesc Psychiatry. 2009;48:511-8.

15. Zhu B, Edson-Heredia E, Cameron GS, et al. Early clinical response as a predictor of subsequent response to ixekizumab treatment: results from a phase II study of patients with moderate-to-severe plaque psoriasis. Br J Dermatol. 2013;169:1337-41.

16. Baker JF, Ostergaard M, Emery P, et al. Early MRI measures independently predict 1-year and 2-year radiographic progression in rheumatoid arthritis: secondary analysis from a large clinical trial. Ann Rheum Dis. 2014;73(11):1968-74.

17. Rousseau C, Devillers A, Sagan C, et al. Monitoring of early response to neoadjuvant chemotherapy in stage II and III breast cancer by [18F]fluorodeoxyglucose positron emission tomography. J Clin Oncol. 2006;24:5366-72.

18. Ascher-Svanum H, Nyhuis AW, Faries DE, Kinon BJ, Baker RW, Shekhar A. Clinical, functional, and economic ramifications of early nonresponse to antipsychotics in the naturalistic treatment of schizophrenia. Schizophr Bull. 2008;34:1163-71.

19. Gavin JR 3rd, Bohannon NJ. A review of the response to oral antidiabetes agents in patients with type 2 diabetes. Postgrad Med. 2010;122:43-51.

20. Hanefeld M, Bramlage P. Insulin use early in the course of type 2 diabetes mellitus: the ORIGIN trial. Curr Diab Rep. 2013;13:342-9.

21. Owens DR. Clinical evidence for the earlier initiation of insulin therapy in type 2 diabetes. Diabetes Technol Ther. 2013;15:776-85.

22. Wagner EH, Sandhu N, Newton KM, McCulloch DK, Ramsey SD, Grothaus LC. Effect of improved glycemic control on health care costs and utilization. JAMA. 2001;285:182-9.

23. Karl D, Zhou R, Vlajnic A, Riddle M. Fasting plasma glucose 6-12 weeks after starting insulin glargine predicts likelihood of treatment success: a pooled analysis. Diabet Med. 2012;29:933-6.

24. Schernthaner G, Matthews DR, Charbonnel B, Hanefeld M, Brunetti P, Quartet [corrected] Study Group. Efficacy and safety of pioglitazone versus metformin in patients with type 2 diabetes mellitus: a double-blind, randomized trial. J Clin Endocrinol Metab. 2004;89:6068-76.

25. Charbonnel BH, Matthews DR, Schernthaner G, Hanefeld M, Brunetti P, QUARTET Study Group. A long-term comparison of pioglitazone and gliclazide in patients with Type 2 diabetes mellitus: a randomized, double-blind, parallelgroup comparison trial. Diabet Med. 2004;22:399-405.

26. Buse JB, Wolffenbuttel BH, Herman WH, et al. The DURAbility of Basal versus Lispro mix 75/25 insulin Efficacy (DURABLE) trial: comparing the durability of lispro mix 75/25 and glargine. Diabetes Care. 2011;34:249-55. doi:10.2337/dc10-1701.

27. Stratton IM, Adler AI, Neil HA, et al. Association of glycaemia with macrovascular and microvascular complications of type 2 diabetes (UKPDS 35): prospective observational study. BMJ. 2000;321:405-12.

28. National Collaborating Centre for Chronic Conditions and the Centre for Clinical Practice at NICE, National Institute for Health and Clinical Excellence, National Health Service. NICE clinical guideline 87 . Type 2 diabetes: the management of type 2 diabetes. 2009. http://www.nice.org.uk/ guidance/ta203/resources/nice-recommends-liraglu tide-for-type-2-diabetes-mellitus4. Accessed Nov 2014.

29. National Institute for Health and Care Excellence. NICE technology appraisal guidance 203. Liraglutide for the treatment of type 2 diabetes mellitus. 2010. http://www.nice.org.uk/guidance/ ta203/resources/guidance-liraglutide-for-the-treatm ent-of-type-2-diabetes-mellitus-pdf. Accessed November 2014.

30. American Diabetes Association. Standards of medical care in diabetes-2011. Diabetes Care. 2011;34(suppl 1):S11-61.

31. Friedman JH. Stochastic gradient boosting. Comput Stat Data Anal. 2002;38:367-78.

32. Shao J. Mathematical statistics, 2nd edn, Springer texts in statistics. New York: Springer; 2003.

33. Banerji MA, Dunn JD. Impact of glycemic control on healthcare resource utilization and costs of type 2 diabetes: current and future pharmacologic approaches to improving outcomes. Am Health Drug Benefits. 2013;6(7):382-92.

34. Esposito K, Chiodini P, Bellastella G, Maiorino MI, Giugliano D. Proportion of patients at HbA1c target $<7 \%$ with eight classes of antidiabetic drugs in type 2 diabetes: systematic review of 218 randomized 
controlled trials with 78945 patients. Diabetes Obes Metab. 2012;14(3):228-33.

35. Nichols GA, Kimes TM, Harp JB, Kou TD, Brodovicz KG. Glycemic response and attainment of A1C goals following newly initiated insulin therapy for type 2 diabetes. Diabetes Care. 2012;35:495-7.

36. Committee on Quality of Health Care in America, Institute of Medicine. Crossing the quality chasm: A new health system for the 21st century. Washington, DC: National Academies Press; 2001.

37. Hastie T, Tibshirani R, Friedman J. The elements of statistical learning. 2nd ed. New York: Springer; 2009.
38. Office of Surveillance and Biometrics, Division of Biostatistics, Diagnostic Devices Branch, Center for Devices and Radiological Health, Food and Drug Administration, US Department of Health and Human Services. Guidance for Industry and FDA Staff: Statistical Guidance on Reporting Results from Studies Evaluating Diagnostic Tests. Published March 13, 2007. Washington, DC: Office of Surveillance and Biometrics, Division of Biostatistics, Diagnostic Devices Branch, Center for Devices and Radiological Health, Food and Drug Administration, US Dept of Health and Human Services; March 13, 2007. 